\title{
Tree-ring based precipitation variability since AD 1828 in northwestern Liaoning, China
}

\author{
Junjie Peng ${ }^{a}$, Yu Sun ${ }^{a}$, Ming Chen ${ }^{b}$, Xingyuan He ${ }^{a}$, Nicole K. Davi ${ }^{c}$, Xianliang Zhang ${ }^{a}$, Teng Li $^{\mathrm{a}}$, \\ Cuiying Zhu ${ }^{\mathrm{b}}$, Chao Cai ${ }^{\mathrm{b}}$, Zhenju Chen ${ }^{\mathrm{a}, \mathrm{d}, *}$ \\ ${ }^{a}$ State Key Laboratory of Forest and Soil Ecology, Institute of Applied Ecology, Chinese Academy of Sciences, Shenyang 110164, China \\ ${ }^{\mathrm{b}}$ Yiwulv Mountain National Nature Reserve, Beizhen 121300, China \\ ${ }^{\mathrm{c}}$ Tree-Ring Laboratory, Lamont-Doherty Earth Observatory, Columbia University, NY 10964, USA \\ ${ }^{\mathrm{d}}$ Research Station of Liaohe-River Plain Forest Ecosystem, Shenyang Agriculture University, Changtu 112500, China
}

\section{A R T I C L E I N F O}

\section{Article history:}

Available online $\mathrm{xxx}$

\begin{abstract}
A B S T R A C T
A 183-year record of total precipitation from September to current July was reconstructed using tree rings from Chinese pine (Pinus tabulaeformis) to explore regional moisture variations in northwestern Liaoning province. The reconstruction accounts for $35.4 \%$ of the total variance of the instrumental precipitation from 1957 to 2010 . The reconstruction shows eleven persistent dry periods (e.g. 1856-1866, 1886-1891, 1898-1905), and eleven persistent wet periods (e.g. 1835-1855, 1867-1878, 1892-1897). Spectral analysis of the reconstruction shows several significant spectral peaks in the ca. 2-4-year periodicity band, suggesting inter-annual variability of El Niño-Southern Oscillation (ENSO). The precipitation reconstruction shows correlations related to the East Asian Monsoon and possible teleconnection of regional moisture variations to Pacific Ocean signals, such as El Niño and La Niña.
\end{abstract}

(c) 2012 Elsevier Ltd and INQUA. All rights reserved.

\section{Introduction}

In recent decades, intense droughts and flooding have caused major regional Chinese natural disasters (Weng et al., 2011), particularly in northern China where significant increases in drought area and prolonged dry periods have occurred (Zou et al., 2005). These climatic extremes can have significant impacts on the stability of development, economies, and society. Northeast China has also experienced persistent climate extremes, especially in northwestern Liaoning province, which has the largest interannual precipitation variations and the longest consecutive days with no rain (Sun et al., 2000). This paper develops a tree-ring based reconstruction of precipitation in an effort to better understand long-term climate variations and possible dynamical forcings. Instrumental records for this region are scarce and short, limiting ability to understand multi-decadal or centennial-scale climate variability. Proxies, such as tree rings, can shed light on the full range of variability over the past several hundred years, which could aid in water resource management and development.

\footnotetext{
* Corresponding author. State Key Laboratory of Forest and Soil Ecology, Institute of Applied Ecology, Chinese Academy of Sciences, Wenhua Road 72, Shenyang 110164, China.

E-mail address: zhenjuchen@hotmail.com (Z. Chen).
}

Tree rings, which may be precisely dated at high resolution and may provide continuous climatic information, are an ideal proxy widely used for reconstruction (Fritts, 1976; Esper et al., 2002; Pauling et al., 2006; Cook et al., 2010; Meko et al., 2011). Although a large number of tree-ring-based paleoclimate reconstructions are available in China, most of these reconstructions are restricted to Central China (Cai et al., 2010; Liu et al., 2008), Western China (Wang et al., 2008; Fang et al., 2009, 2010; Gou et al., 2010; Shao et al., 2010; Zhang et al., 2011a,b), North-central China (Li et al., 2007; Liu et al., 2010; Yi et al., 2010) and Northwest China (Liu et al., 2004; Gao et al., 2005; Yang et al., 2011), with only a few dendroclimatic reconstructions in Northeast China (Yu et al., 2007, 2011; Zhu et al., 2009; Chen et al., 2011; Zhang et al., 2011a,b). Thus, more tree-ring studies are needed to fill the wide geographic data gap in this region.

Furthermore, seasonal moisture conditions over southern Northeast China are influenced by the Pacific Ocean (Chen et al., 2011), particularly the Asian Monsoon (Li and Zeng, 2003) and El Niño-Southern Oscillation (ENSO). Therefore it is possible to explore the linkages between long-term year-round rainfall variability in southern Northeast China with the Pacific Ocean.

This study reconstructed prior September to current July precipitation (1828-2010) and assessed rainfall-based moisture patterns for Yiwulv Mountain, in northwestern Liaoning province. The goals of this study were to (1) identify the limiting climate 
factors of local tree growth through investigation of climate-growth responses; (2) reconstruct precipitation as well as dryness and wetness variation patterns; and (3) explore the variability of the reconstruction and its large-scale linkages, such as to the tropical Pacific Ocean.

\section{Material and methods}

\subsection{Study area}

The study area is located in northwestern Liaoning province, along the southern boundary of the Keerqin Sandy Lands (Fig. 1). It is a zone between semiarid and semihumid conditions controlled by continental monsoon climate regimes where droughts and floods occur frequently (Xiong et al., 2011). The sampling site, Yiwulv Mountain ( $41^{\circ} 36^{\prime} 35^{\prime \prime} \mathrm{N}, 121^{\circ} 41^{\prime} 42^{\prime \prime} \mathrm{E}, 415 \mathrm{~m}$ above sea level [a.s.l.]) is characterized by Chinese pine (Pinus tabulaeformis) forests and mixed deciduous-conifer forest. The regional dominant tree species are Chinese pine and Quercus mongolica. Lespedeza bicolor, Corylus heterophylla, Vitex negundo and other species are present beneath the canopy.

\subsection{Meteorological data}

The meteorological data were obtained from the China Meteorological Data Sharing Service System (http://cdc.cma.gov.cn/). Data from the two meteorological stations closest to the sampling site, Heishan station (HS, $41^{\circ} 41^{\prime} \mathrm{N}, 122^{\circ} 05^{\prime} \mathrm{E}, 37.5 \mathrm{~m}$ a.s.l., 1956-2010) and Fuxin station (FX, $42^{\circ} 05^{\prime} \mathrm{N}, 121^{\circ} 43^{\prime} \mathrm{E}, 167.8 \mathrm{~m}$ a.s.l., 1951-2010) were obtained (Fig. 1). Maximum monthly precipitation is found in July (HS: $159.8 \mathrm{~mm}, \mathrm{FX}: 139.4 \mathrm{~mm})$, and minimum monthly precipitation is found in January (HS: $3.0 \mathrm{~mm}$,

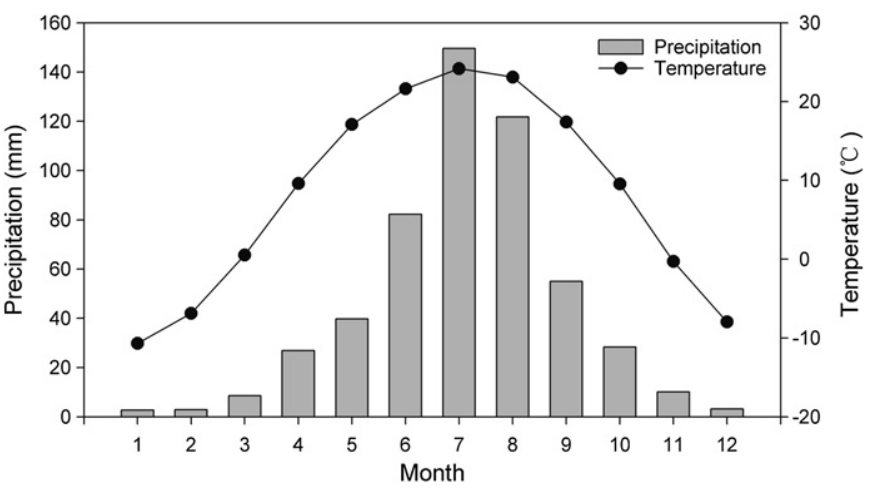

Fig. 2. Mean monthly temperature (curve) and precipitation (histogram) calculated by averaging the instrumental records for Heishan (HS) and Fuxin (FX) meteorological stations during the common period of 1956-2010.

FX: $2.5 \mathrm{~mm}$ ) during the common period 1956-2010. Precipitation from June to August accounts for a major part ( $66 \%$ ) of annual precipitation. Significant correlations were found between the two stations for temperature $(r=0.958(0.915-0.988), p<0.01)$ and precipitation $(r=0.792(0.622-0.914), p<0.01)$. In order to decrease the effects of environmental heterogeneity, regional climate series were created by averaging the meteorological data from the two stations over the common interval of 1956-2010 (Fig. 2).

\subsection{Tree-ring data and chronology development}

Ninety-seven cores were taken from 56 living Chinese pines in stands scarcely disturbed by human activities. Conventional

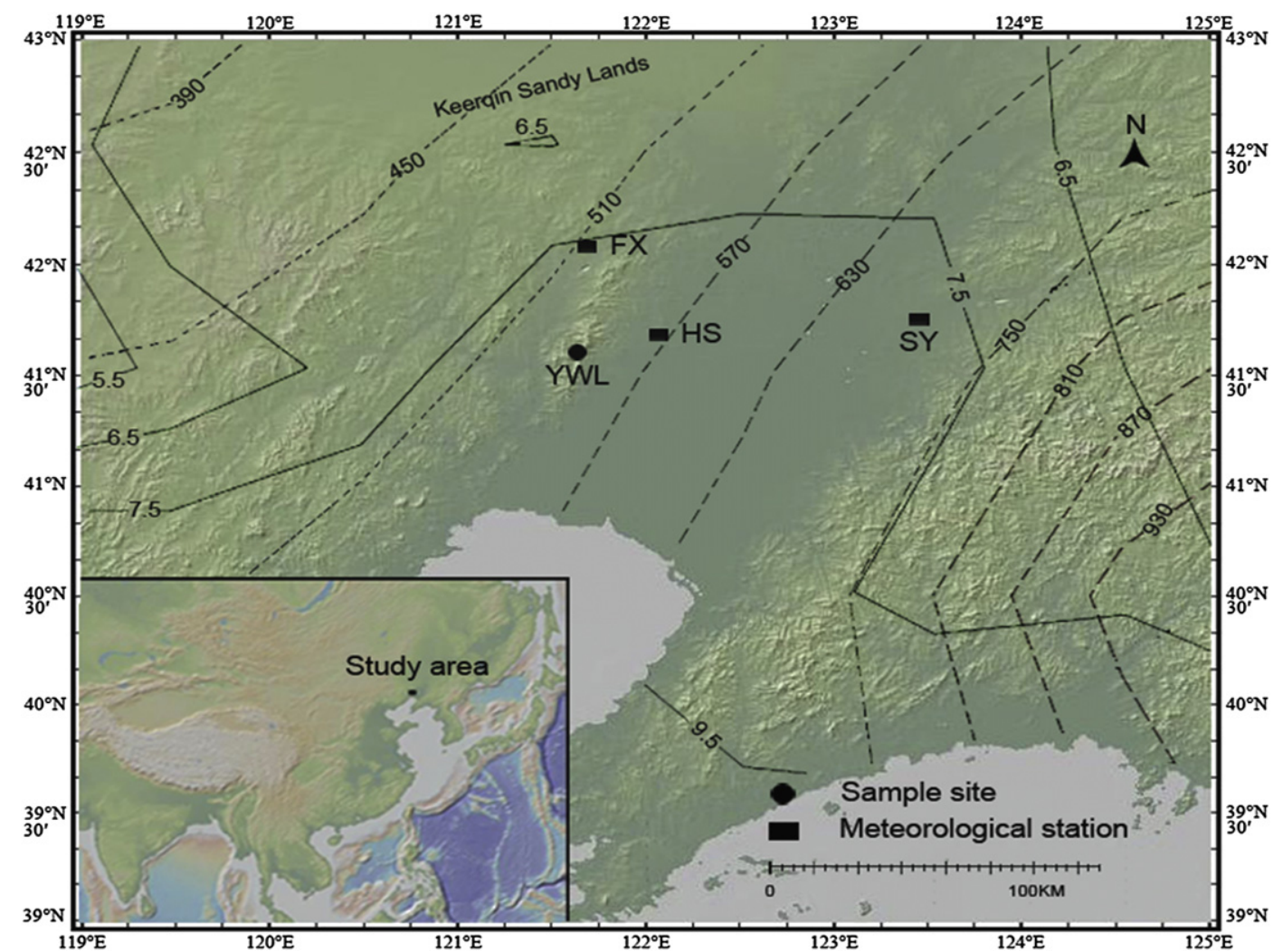

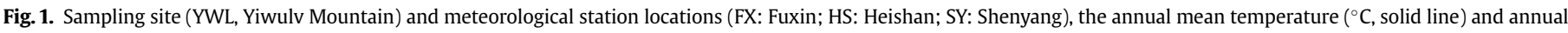
precipitation (mm, dashed line) of the CRU TS $3.11^{\circ} \times 1^{\circ}$ grid for the period of $1957-2009$ in the study area (available at http://climexp.knmi.nl/). 
Table 1

The standard of dryness/wetness index and its corresponding moisture condition.

\begin{tabular}{|c|c|c|c|}
\hline Index value & Moisture condition & Standard of dryness and wetness & Standard of dryness and wetness in this study \\
\hline 1 & Wetness & $P_{i}>\left(P_{\text {mean }}+1.17 S\right)$ & $P_{i}>515.0 \mathrm{~mm}$ \\
\hline 2 & Weak wetness & $\left(P_{\text {mean }}+0.33 S\right)<P_{i} \leq\left(P_{\text {mean }}+1.17 S\right)$ & $446.1 \mathrm{~mm}<P_{i} \leq 515.0 \mathrm{~mm}$ \\
\hline 3 & Normal & $\left(P_{\text {mean }}-0.33 S\right)<P_{i} \leq\left(P_{\text {mean }}+0.33 S\right)$ & $392.0 \mathrm{~mm}<P_{i} \leq 446.1 \mathrm{~mm}$ \\
\hline 4 & Weak dryness & $\left(P_{\text {mean }}-1.17 S\right)<P \leq\left(P_{\text {mean }}-0.33 S\right)$ & $323.2 \mathrm{~mm}<P_{i} \leq 392.0 \mathrm{~mm}$ \\
\hline 5 & Dryness & $P_{i} \leq P_{\text {mean }}-1.17 S$ & $P_{i} \leq 323.2 \mathrm{~mm}$ \\
\hline
\end{tabular}

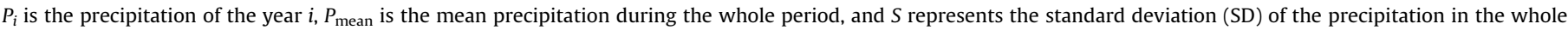
period.

dendrochronological techniques (Fritts, 1976) were used to develop the tree-ring width chronologies: the samples were mounted, air dried, sanded and visually crossdating. After crossdating, tree-ring widths were measured with a LINTAB5 measuring system at a resolution of $0.001 \mathrm{~mm}$, and crossdating was checked using the COFECHA program (Holmes, 1983). A negative exponential or linear curve was used for each ring-width series to remove the biological growth trend and effects of stand dynamics not related to climate variations in ARSTAN (Cook, 1985). In the few cases where anomalous growth trends could not be fitted by either method, a cubic spline curve with a 50\% frequency response cutoff equal to $2 / 3$ of each series length was used. To remove the potential influence of growth in previous years, autoregressive modeling was applied after detrending. A robust mean was calculated to reduce the bias caused by outliers related to endogenous stand disturbances. Combining all detrended ring-width series, a 214-year chronology covering 1797 to 2010 was then created by computing bi-weighted robust means (Cook and Kairiukstis, 1990). Finally, three kinds of chronologies were obtained: the Standard chronology (STD), the Residual chronology (RES) and the ARSTAN chronology (ARS). Both the STD and ARS chronologies preserve similar high and low frequencies that represent the common signal (Cook and Kairiukstis, 1990). Specifically, the STD is produced by simple averaging and the ARS by pooled autoregressive model reincorporated into the RES. However, the ARS can reduce the effects of competition in closed canopy forests (Cook, 1985). In contrast, the RES captures high frequencies by using autoregressive methods to remove the effects of growth in one year on the following year.

The reliability of the chronology was assessed by the inter-series correlation (RBAR) and the expressed population signal (EPS) (Wigley et al., 1984). Both RBAR and EPS were computed over 50year moving windows with 25-year overlaps. An EPS of 0.85 or above is a suggested acceptance level for chronology quality, and indicates the chronology is sufficiently replicated to represent the theoretical population based on an infinite number of trees (Briffa and Jones, 1990). Several descriptive statistics including mean, median, standard deviation (SD), first-order autocorrelation (AC1), and the coefficients of skewness and kurtosis were calculated.

The climate-growth relationship between the chronologies and meteorological data was examined by simple Pearson correlation analysis for a 24-month period. To demonstrate the regional representation of the reconstruction and instrumental records, the actual and reconstructed series were correlated with regional

Table 2

The statistics of the Standard (STD), Residual (RES) and ARSTAN (ARS) chronologies.

\begin{tabular}{llll}
\hline Parameters/Chronology & STD & RES & ARS \\
\hline Mean & 1.022 & 0.989 & 0.989 \\
Median & 0.964 & 0.979 & 0.961 \\
Mean sensitivity & 0.241 & 0.292 & 0.239 \\
Standard deviation & 0.362 & 0.271 & 0.346 \\
Skewness & 0.971 & 0.453 & 0.922 \\
Kurtosis & 1.571 & 0.822 & 1.901 \\
First-order autocorrelation & 0.638 & 0.051 & 0.619 \\
\hline
\end{tabular}

gridded $\left(1^{\circ} \times 1^{\circ}\right)$ data $\left(38^{\circ}-54^{\circ} \mathrm{N}, 110^{\circ}-135^{\circ} \mathrm{E}\right)$ of CRU (Climate Research Union, UK) TS 3.1 (Mitchell and Jones, 2005). Spatial correlations were performed using the KNMI Climate Explorer (http://climexp.knmi.nl/).

Spectral analysis can be used to extract the non-random signals preserved in time series (Fritts, 1976). For the purpose of exploring the possible mechanism that affects climate variability in the region, the Multi-Taper Method (MTM) spectral analysis (Mann and Lee, 1996) was applied to examine the frequency domain in the series (MTM software is available at http://www.ldeo. columbia.edu/res/fac/trl/). In addition, a dryness/wetness index with five grades based on the standard of Editorial Committee of Academy of Meteorological Science, China Central Meteorological Administration (1981) is shown in Table 1.

\section{Results}

\subsection{Regional climate variability and chronology statistics}

During the past 55 years (1956-2010), annual mean temperature has increased significantly $\left(0.23{ }^{\circ} \mathrm{C}\right.$ decade $\left.^{-1}, p<0.01\right)$. Meanwhile, regional spring and summer mean temperatures have also significantly $(p<0.01)$ increased by $0.46{ }^{\circ} \mathrm{C}$ decade $^{-1}$ and $0.15{ }^{\circ} \mathrm{C}$ decade ${ }^{-1}$, respectively. Recorded precipitation shows decreasing trends for annual precipitation and seasonal trends in precipitation in spring and summer that are not significant.

The values of mean sensitivity (MS) $(0.241,0.292$, and 0.239 for STD, RES and ARS, respectively) represent the magnitude of interannual ring width variability between adjacent rings, which are sufficiently high to indicate climate sensitivity. First-order autocorrelation ranged from 0.051 to 0.638 , the upper values of which suggest that climate of the previous year influences tree growth of the current year (Table 2). The EPS and mean interseries correlation statistics range from 0.932 to 0.983 and 0.198 to 0.387 , respectively

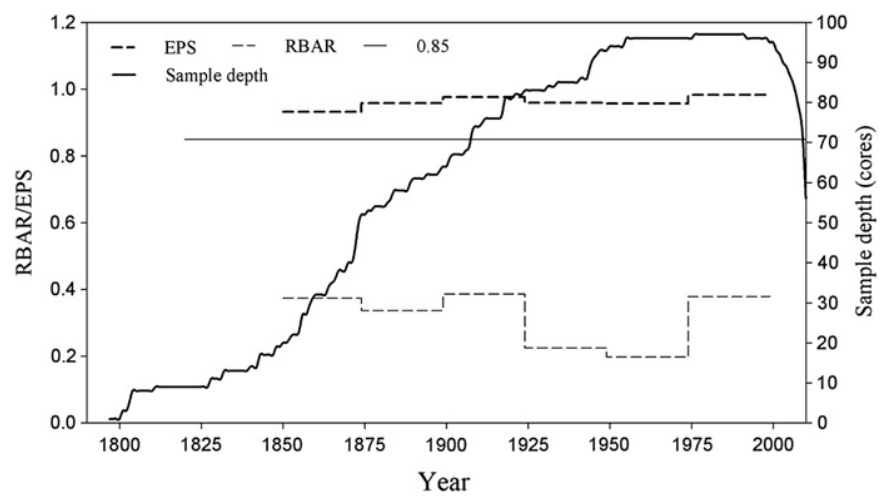

Fig. 3. The running RBAR (mean interseries correlation, thin dashed line), EPS (expressed population signal, thick dashed line) and sample depth (thick solid line). Both RBAR and EPS were calculated by 50 -year moving windows with 25 -year overlaps. The threshold of EPS is 0.85 (thin horizontal line), above which is considered to be reliable. 

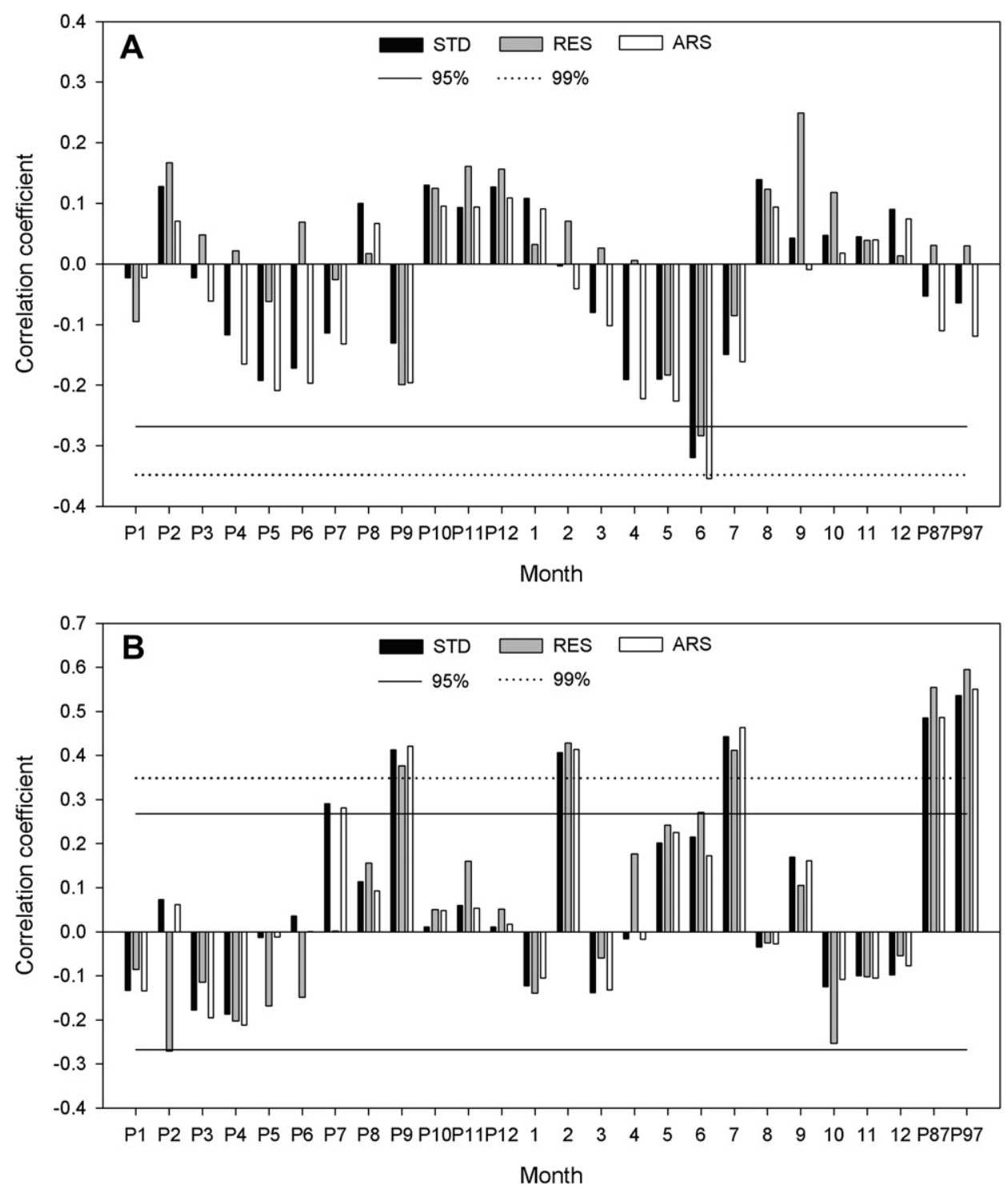

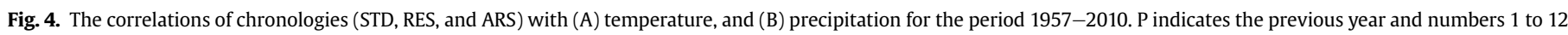

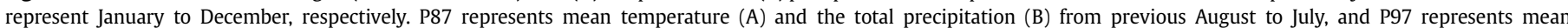

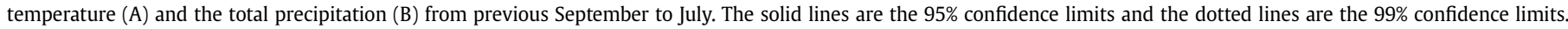

(Fig. 3). Other tree-ring chronology descriptive statistics, including the median (ranging from 0.961 to 0.979 ), SD (ranging from 0.271 to 0.362 ), skewness coefficient (ranging from 0.453 to 0.971 ), kurtosis coefficient (ranging from 0.822 to 1.901 ) were also listed on Table 2. With the threshold of 0.85 for EPS, the master chronology extends from 1828 to 2010, enriching understanding of climate variability in the region by 183 years.

\subsection{Climate-growth relationships}

Correlation analysis (Fig. 4A) shows that temperature in summer negatively correlates with tree growth, especially in June $(p<0.05)$. Precipitation has more influence on tree growth than temperature demonstrated by high correlation coefficients in this region (Fig. 4B). Significant positive correlations $(p<0.01)$ between tree growth and precipitation occur in previous September, current February and July. Seasonally averaged climatic variables are often more representative of climatic conditions during the growing season than just one single month, thus different seasonal combinations of precipitation were tested. The total precipitation from the previous September to current July displays the highest correlations with tree rings $\left(r_{\mathrm{RES}}=0.595, r_{\mathrm{STD}}=0.536, r_{\mathrm{ARS}}=0.550\right.$, $p<0.01)$. Therefore, it is the most appropriate for reconstruction (Fig. 4B).

Table 3

The first-order autocorrelation of the monthly instrumental precipitation in Heishan (HS), Fuxin (FX) and their mean during the common period $1957-2010$.

\begin{tabular}{|c|c|c|c|c|c|c|c|c|c|c|c|c|c|c|}
\hline Month & Jan & Feb & Mar & Apr & May & Jun & Jul & Aug & Sep & Oct & Nov & Dec & P97 & Annual \\
\hline HS & 0.134 & -0.033 & -0.207 & -0.088 & -0.101 & -0.040 & -0.099 & 0.134 & $0.384^{*}$ & -0.084 & -0.079 & -0.089 & 0.044 & 0.149 \\
\hline FX & 0.152 & -0.166 & -0.116 & 0.050 & -0.030 & -0.110 & 0.085 & 0.072 & $0.383^{*}$ & -0.095 & -0.142 & 0.036 & 0.038 & -0.001 \\
\hline Mean & 0.149 & -0.106 & -0.176 & -0.036 & -0.084 & -0.035 & 0.004 & 0.130 & $0.458^{* *}$ & -0.086 & -0.108 & -0.042 & 0.094 & -0.036 \\
\hline
\end{tabular}

The P indicates the previous year and P97 is the total precipitation from previous September to July. ${ }^{*}$ Significant at $p<0.05{ }^{* *}$ Significant at $p<0.01$. 


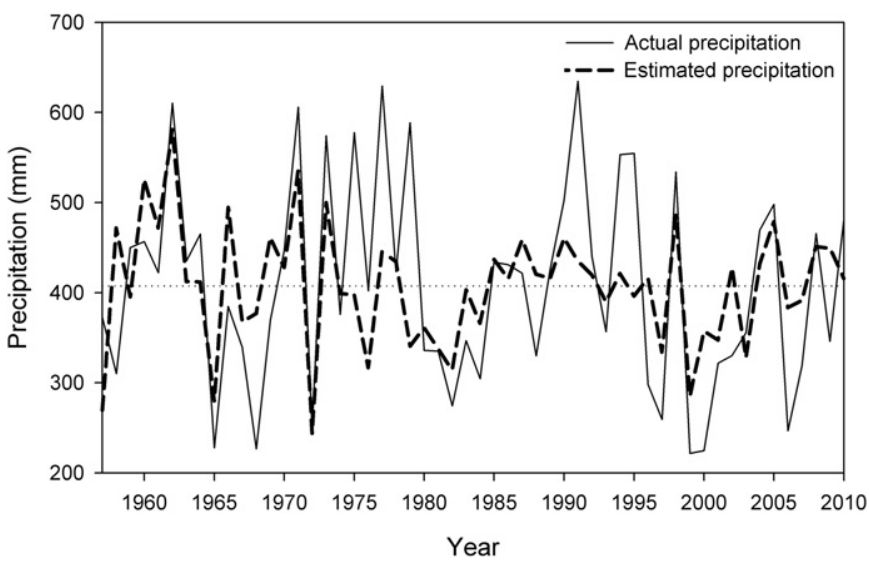

Fig. 5. Comparison of actual (solid line) and estimated (dashed line) precipitation from previous September to July during the period of 1957-2010. Horizontal dotted line represents the average of the instrumental precipitation.

\subsection{Precipitation reconstruction}

According to the above analysis, the RES-based reconstruction explains the highest variance of actual precipitation from previous September to current July $\left(R^{2}=0.354\right)$ in comparison with other two chronologies. The first-order autocorrelation coefficients (AC1) for most precipitation series (1957-2010) indicate the regional precipitation has "white noise" features, and thus the precipitation in this area is apparently characterized by high-frequency variations (Table 3). Therefore, further discussion of tree-ring-based precipitation will be the main focus of RES results. The reconstructed precipitation agrees well with the observed data during the period 1957-2010 (Fig. 5). Split-sample calibration-verification (Meko and Graybill, 1995) and leave-one-out cross-verification methods (Michaelsen, 1987) were employed to evaluate the statistical fidelity of the reconstruction series (Table 4). Both the reduction error (RE) and the coefficient of efficiency (CE) are positive, confirming the regressive model. In addition, the results of the leave-one-out method also demonstrate the fidelity of the reconstruction.

According to the dry-wet standard defined by the Editorial Committee of the Academy of Meteorological Science (Table 1),

Table 4

Statistics of calibration and verification test for the common period 1957-2010.

\begin{tabular}{|c|c|c|c|c|c|}
\hline & Calibration & Verification & Calibration & Verification & Final calibration $^{\mathrm{b}}$ \\
\hline & 1957-1985 & 1986-2010 & 1986-2010 & 1957-1985 & 1957-2010 \\
\hline$r$ & 0.591 & 0.656 & 0.656 & 0.591 & $\begin{array}{l}0.595 \\
(0.560-0.647)\end{array}$ \\
\hline$r^{2}$ & 0.349 & & 0.431 & & $\begin{array}{l}0.354 \\
(0.313-0.418)\end{array}$ \\
\hline$r_{\text {adjusted }}^{2}$ & 0.325 & & 0.406 & & $\begin{array}{l}0.341 \\
(0.300-0.407)\end{array}$ \\
\hline$F$ & & & & & $\begin{array}{l}28.484 \\
(23.282-36.693)\end{array}$ \\
\hline$P$ & & & & & $<0.0001$ \\
\hline $\mathrm{RE}$ & 0.349 & 0.338 & 0.431 & 0.117 & \\
\hline $\mathrm{CE}$ & 0.349 & 0.330 & 0.431 & 0.107 & \\
\hline Sign test & $23+16-{ }^{* *}$ & $20+/ 5-^{* *}$ & $23+/ 6-^{* *}$ & $20+15-^{* *}$ & \\
\hline$t-$ stat $^{\mathrm{a}}$ & 1.385 & $1.896^{*}$ & $2.672^{* *}$ & $1.992^{*}$ & \\
\hline
\end{tabular}

$r$, correlation coefficient for the calibration-verification period; $r^{2}$, explained variance of the regression model for the calibration-verification period; $r_{\text {adjusted, }}^{2}$ adjusted for the loss of degrees of freedom; RE is the reduction of error and CE is the coefficient of efficiency.

${ }^{*}$ Significant at $p<0.05,{ }^{* *}$ significant at $p<0.01$.

a $t$-stat is the $t$ statistic.

b The italic statistics in parentheses indicate the statistical characteristics of leaveone-out verification. a rainfall-based dryness/wetness index was developed for northwestern Liaoning province for the period of 1828-2010 (Fig. 6). Within the 183-year precipitation reconstruction, there are 19 dry years (below $323 \mathrm{~mm}, 10.4 \%$ of the total), 48 weak dry years (range of $323-392 \mathrm{~mm}, 26.2 \%$ of the total), 60 normal years (range of $392-446 \mathrm{~mm}, 32.8 \%$ of total), 36 weak wet years (range of $446-514 \mathrm{~mm}, 19.7 \%$ of total), and 20 wet years (above $514 \mathrm{~mm}$, $10.9 \%$ of total). Dry (including mildly dry) or wet (including mildly wet) periods equal to or greater than 3 year are listed in Table 5. The driest year occurred in 1835 , while the wettest year occurred in 1841. The 1920s were the driest decade and the 1840 s were the wettest decade. After an 11-year low-pass filter method was applied to the rainfall reconstruction, 11 wet periods with aboveaverage precipitation $(419 \mathrm{~mm})$ and 11 relative dry periods with below-average precipitation were identified (Fig. 6A).

Spatial correlations indicate that this reconstruction was able to capture regional precipitation variations. Specifically, the instrumental and reconstructed precipitation significantly correlate with regional gridded September-July precipitation, especially from $38^{\circ}$ to $48^{\circ} \mathrm{N}, 113^{\circ}-126^{\circ} \mathrm{E}$ (Fig. 7), suggesting a common profile of dryness/wetness variation at the regional scale.

The MTM spectral analysis for the instrumental and reconstructed precipitation series indicate some quasi-periodic behavior (Fig. 8). Significant $(p<0.05)$ spectral peaks at ca. 3.4-3.5, and highly significant $(p<0.01)$ spectral peaks at ca. $2.0-2.3$ years are found in the instrumental record. Meanwhile, significant $(p<0.05)$
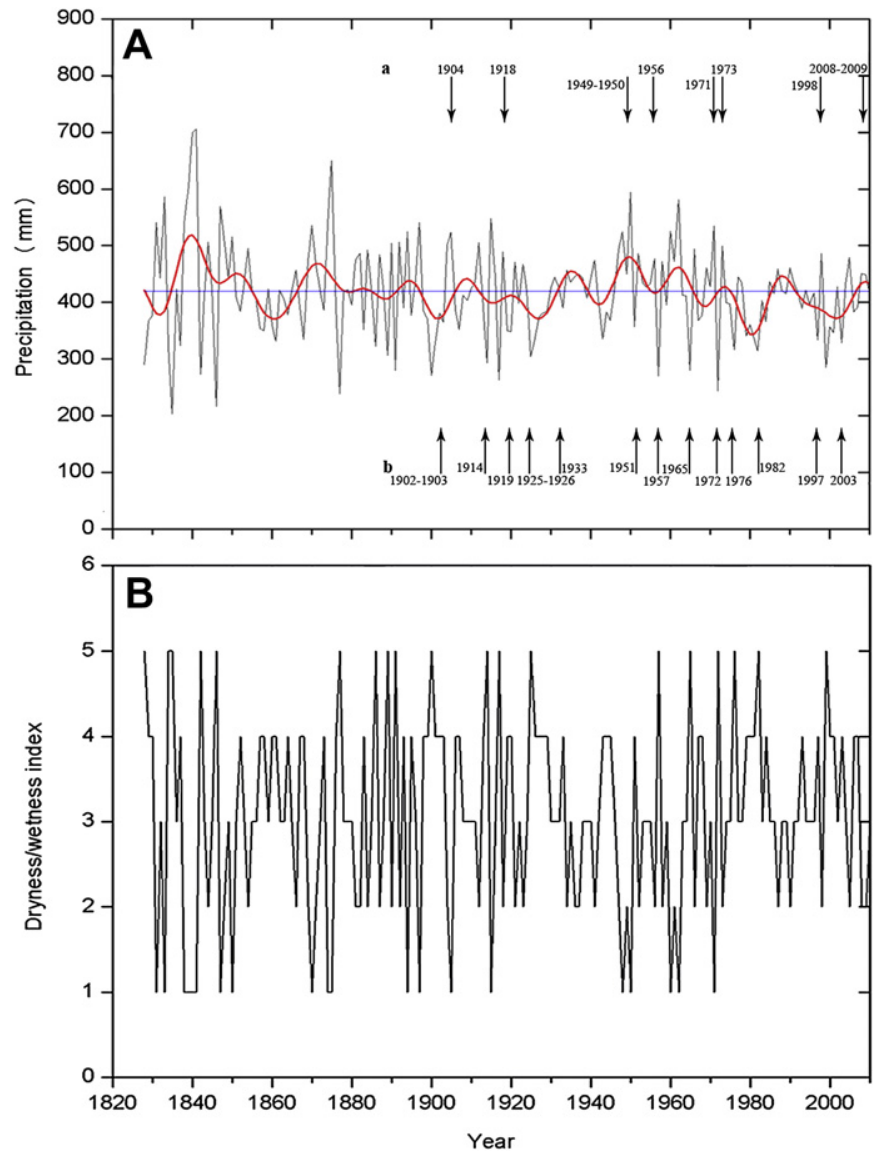

Fig. 6. (A) The reconstructed precipitation (thin curve) from previous September to July and the mean (horizontal line) for 1828-2010. The thick smoothed curve shows an 11 -year low-pass filter value. Arrows labeled by years indicate (a) major La Niña years and (b) major El Niño years (http://www.bom.gov.au/climate/enso/lnlist/index.shtml). (B) Estimated September-July dryness/wetness index according to the definition of the Editorial Committee of Academy of Meteorological Science (1981). 
Table 5

Periods with 3 or more consecutive years' dryness/wetness from the reconstruction.

\begin{tabular}{llllll}
\hline Dry/wet & Period & $\begin{array}{l}\text { Duration } \\
\text { (years) }\end{array}$ & $\begin{array}{l}\text { Maximum } \\
(\mathrm{mm})\end{array}$ & $\begin{array}{l}\text { Minimum } \\
(\mathrm{mm})\end{array}$ & $\begin{array}{l}\text { Mean } \\
(\mathrm{mm})\end{array}$ \\
\hline Dry & $1828-1830$ & 3 & 376.6 & 290.5 & 345.1 \\
& $1898-1903$ & 6 & 386.6 & 271.0 & 350.4 \\
& $1925-1929$ & 5 & 383.7 & 303.7 & 355.9 \\
& $1943-1945$ & 3 & 383.1 & 335.5 & 362.1 \\
& $1979-1982$ & 4 & 361.0 & 314.1 & 338.4 \\
\multirow{3}{*}{ Wet } & $1999-2001$ & 3 & 357.2 & 285.0 & 329.7 \\
& $1838-1841$ & 4 & 705.5 & 539.4 & 637.3 \\
& $1869-1871$ & 3 & 535.5 & 468.9 & 492.5 \\
& $1947-1950$ & 4 & 594.8 & 449.8 & 515.2 \\
& $1960-1962$ & 3 & 581.2 & 471.8 & 526.2 \\
\hline
\end{tabular}

spectral peaks at ca. 2.1, 3.0-3.2, 3.8, 8.6 and 8.7 years are found in the entire reconstructed precipitation.

\section{Discussion}

\subsection{Climate-growth response}

Precipitation is one of the main limiting factors for tree growth in this region, particularly during the growing season. In general, an increase of precipitation during the growing season results in wider ring formation due to an increased rate of photosynthesis and improved cell division and cell enlargement process (Fritts, 1976). Winter precipitation positively affects trees, likely because the greater moisture storage benefits the tree during the following growing season. Sufficient spring precipitation directly increases the soil moisture availability and satisfies the water demand at the start of cambial activity (Chen et al., 2011). Therefore, precipitation in February and May favors tree growth (Fig. 4B). In addition, the sampling site is located in a semiarid region with nutrient-poor and thin soil layers and steep slopes, all of which result in greater sensitivity to water availability than for trees growing in relatively humid regions (Fritts, 1976). More precipitation in the late growing season (September) of the previous year may result in the accumulation of large amounts of stored photosynthates in the trees as well as increased soil water, providing the necessary energy and water for the following year's growth (Liang et al., 2001). There are negative effects on Chinese pine growth during the cold season, e.g. in October-January $(r=-0.176, n=55)$ when temperatures average approx. $-2.35{ }^{\circ} \mathrm{C}$, suggesting that very low winter temperatures may damage trees (Chen et al., 2007). Generally, photosynthesis of trees may still be ongoing after autumn when the growth of tissues and cells ceased (Fritts, 1976). Low temperatures could limit photosynthesis by increasing fine root mortality and foliage damage (Körner, 1998; Rolland et al., 1999). Also, low January temperatures could decrease needle longevity of Chinese pine (Xiao, 2003) and affect subsequent years' tree growth, to a large extent, through earlier leaf fall. High temperatures in summer can also negatively affect tree growth due to increased evapotranspiration and accelerated water loss in semiarid regions, especially on steep slopes. Trees respond to both temperature and precipitation (Fritts, 1976), e.g., the radial growth of Chinese pine positively correlates to precipitation and negatively correlates with temperature. Therefore, the Palmer drought severity index (PDSI) $\left(2.5^{\circ} \times 2.5^{\circ}, 40^{\circ}-42.5^{\circ} \mathrm{N}, 120^{\circ}-122.5^{\circ} \mathrm{E}\right.$, available at http:// climexp.knmi.nl/) was used as a measure of regional moisture availability (Dai et al., 2004). Significant positive correlations between tree growth and monthly PDSI was found from August to December $\left(r_{\text {August-December }}=0.292-0.412, p<0.05, n=50\right)$.

\subsection{Dry/wet assessment}

The reconstruction explained around 35\% of the variance of the instrumental precipitation record, which is significant but not very high for dendroclimatology. Although not up to normal standards (ca. 50\%) for dendroclimatological reconstruction, no other precipitation reconstruction exists for this location. In addition, the location difference (elevation, distance) between the sampling site (mountainous) and the meteorological stations (plains) might reduce the correlation of tree-ring data and rainfall records. However, the precipitation reconstruction preserves the interannual and inter-decadal moisture variations found in the instrumental data well, and provides a new tool to assess the long-term changes in precipitation.

The dominant dry decades and dominant wet decades have broad spatial significance in northern China (Fig. 7B and Fig. 9). The reconstruction was also verified by the century-length instrumental rainfall records and tree-ring based precipitation data at Shenyang, and other tree-ring based precipitation reconstructions, e.g. the precipitation record (1905-2010) in Shenyang (SY, $41^{\circ} 43^{\prime}$ $48^{\prime \prime} \mathrm{N}, 123^{\circ} 27^{\prime} \mathrm{E}, 42 \mathrm{~m}$ a.s.l.) significantly correlates $(r=0.384$, $p<0.01, n=105)$ with the reconstruction. The reconstructed January-May precipitation for Shenyang (Chen et al., 2011) also significantly $(p<0.05)$ correlates to the reconstructed

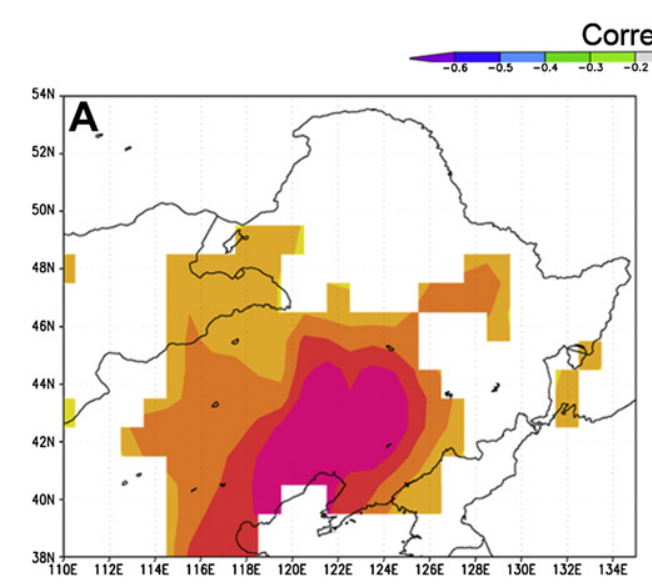

Correlations

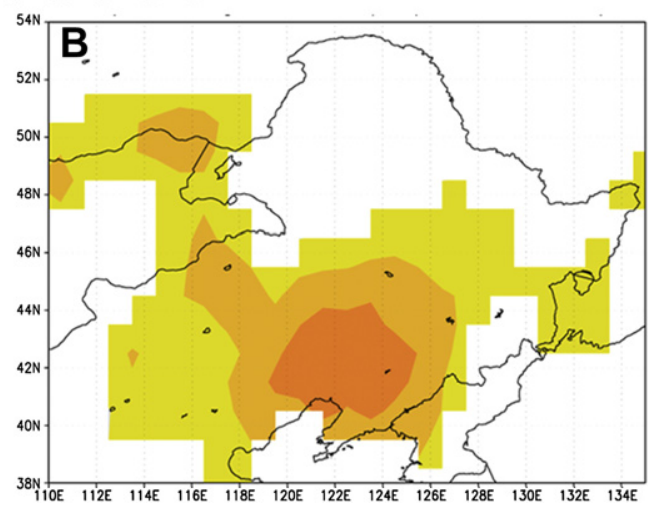

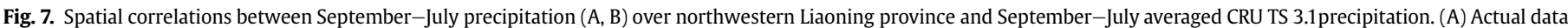

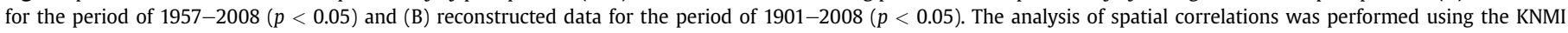
Climate Explorer (http://climexp.knmi.nl/). 

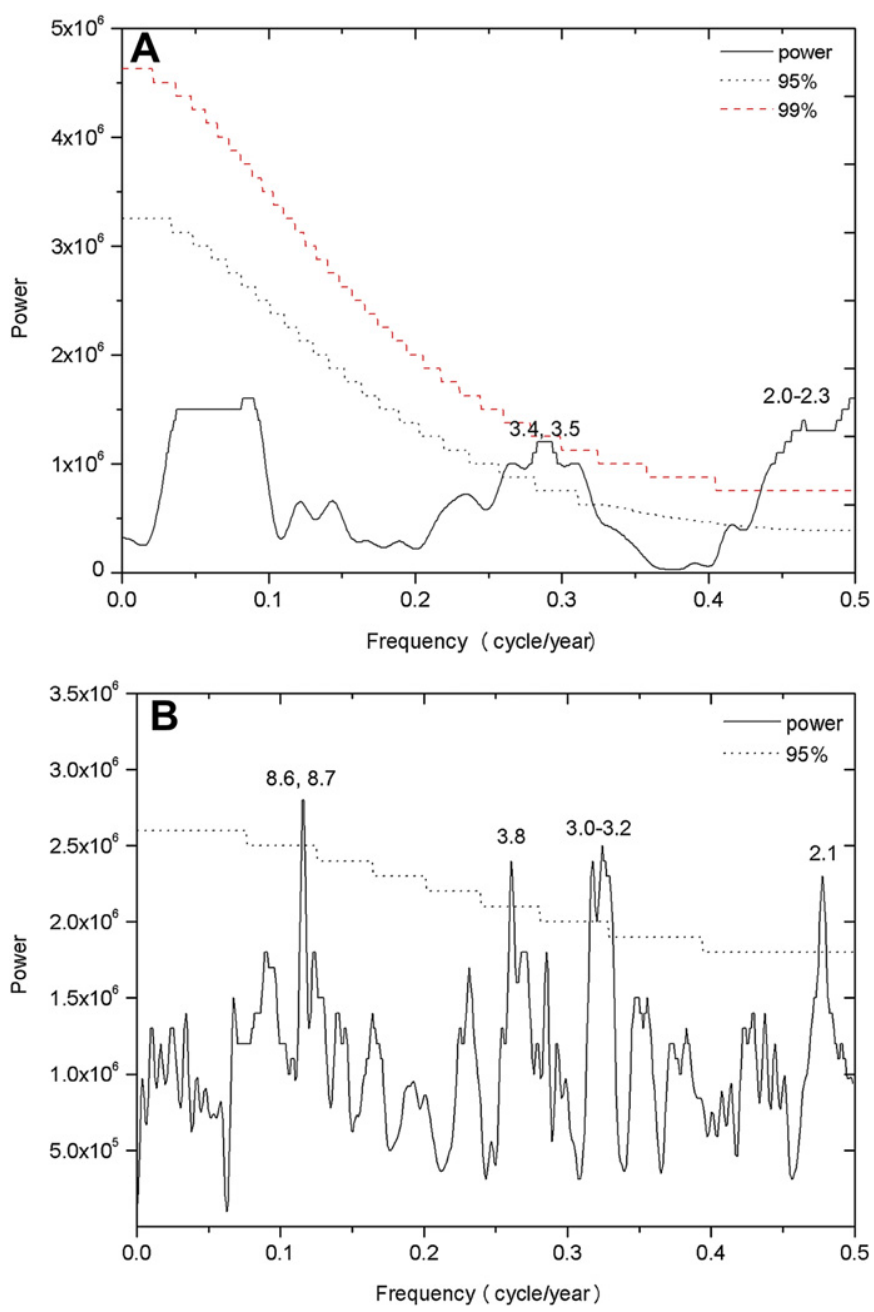

Fig. 8. The Multi-Taper Method (MTM) spectral analysis for (A) actual September-July precipitation for the period of 1957-2010, and (B) reconstructed September-July precipitation for the period of 1828-2010. The multi-taper spectrum of signal component using number of tapers $K=3$, time-frequency bandwidth $p=2$, with peaks labeled by periodicity in years. Curves indicate above $95 \%$ confidence level.

September-July precipitation during the common period 1828-2002, and the reconstructed dry periods 1829-1834, 1856-1866, 1913-1931, 1992-2002 and wet periods 1835-1855, 1867-1878,1945-1955 were clearly detected in the Shenyang reconstruction (Chen et al., 2011). Severe widespread droughts such as those in 1835, 1877-1878, 1927-1928, 1980-1982 and 1986-1989 (Tan, 2003) can cause great loss of life and wealth in China. The reconstruction captures these events well.

Specifically, dominant droughts and pluvials are characterized by their extended duration and severe impacts to the environment prior to the instrumental record, e.g. the drought of 1856-1866 is the longest drought in the 19th century, with mean annual precipitation of $391.2 \mathrm{~mm}$, which is $31.7 \mathrm{~mm}$ lower (deficit) than the mean level of the whole reconstruction. At same time, tree-ring growth from drought sensitive regions such as Baiyinaobao (Liu et al., 2003a), northern Helan Mountains (Liu et al., 2004), and Qilian Mountains (Gou et al., 2001) also clearly decreased. Notably, the 1913-1931 interval is the second longest dry period (19 years) with 10 dry years, including the three minimum rainfall years (1914, 1917 and 1925), widely recorded in many studies over North China (Liang et al., 2006; Li et al., 2007). A drying trend occurring from 1922 to 1931 was also seen in North China (Fu and Wang, 1991) and Northwest China (Fang et al., 2009). The longest wet period of the reconstruction, 1835-1855, is 21 years, with $35 \%$ of total wet years, a period also found in other tree-ring studies (Yang et al., 2005; Chen et al., 2011; Zhang et al., 2011a,b).

The persistent and alternating decadal dryness/wetness mode in recent decades is the most significant feature of the reconstruction. For instance, 1945 to 1965 is a 21-year wet period with a short interruption from 1956 to 1957 . The following 20-year interval, 1966-1985, is a persistent dry period with a short interruption from 1973 to 1975 . This change might suggest some decadal variations in strength in the East Asia Summer Monsoon, especially after the late 1960s (Liu et al., 2003b, 2009). Furthermore, the East Asia Summer Monsoon index of previous June-August (http://www.lasg.ac.cn/staff/ljp/data-monsoon/ EASMI.htm) (Li and Zeng, 2003) is significantly correlated with the reconstructed September-July precipitation (e.g. $r_{\text {June }}=0.262$, $r_{\text {June-August }}=0.311, p<0.05$ ), suggesting that there is a lag effect on local September-July precipitation variability. In addition, the dry period since 1992 (lasting for 15 years) indicates a drying trend (Zou et al., 2005; Li et al., 2007), suggesting that Chinese pines are vulnerable to water deficits in the future.

Significant high-frequency peaks at ca. 2-4-year periodicity $(p<0.05)$ in actual $(2.0-2.3,3.4$, and 3.5$)$ and estimated precipitation $(2.1,3.0-3.2$, and 3.8$)$, as well as significant spectral peaks near 8-year (8.6 and 8.7) in estimated precipitation show good agreement with the characteristics of El Niño-Southern Oscillation (ENSO) variability (Allan et al., 1996) (Fig. 8). However, 8.6 and 8.7 peaks did not appear in the instrumental precipitation, which

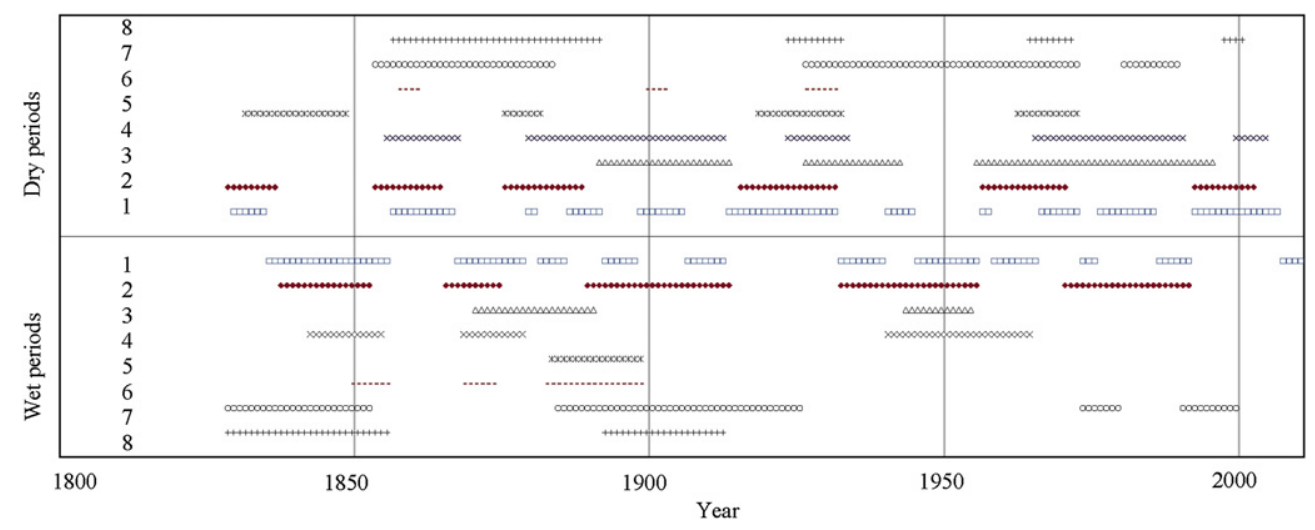

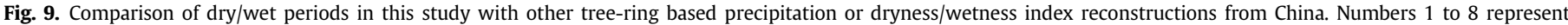

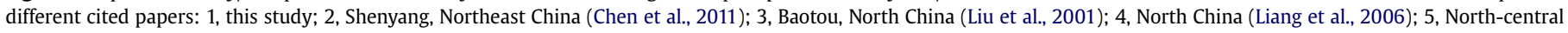
China (region A) (Yi et al., 2010); 6, North-central China (region B) (Yi et al., 2010); 7, Chifeng-Weichang (Liu et al., 2010); 8, Inner Mongolia (Liu et al., 2009). 
might suggest that some combined moisture signals (e.g. precipitation and temperature), which relate to ENSO, exist in the estimated reconstruction, but not in the instrumental record. Moreover, the significant peaks in the ca. 2-4-year periodicity band $(p<0.05)$ were also detected in instrumental January-May precipitation from 1906 to 2002 in Shenyang (Chen et al., 2011). Significantly negative correlation $(r=-0.285, p<0.01, n=141)$ was found between the reconstructed precipitation and annual Niño 3 index for 1870-2010. These findings indicate ENSO might be a dominant forcing to local dryness/wetness variation. Most of the dryness and wetness in the last century coincided with El Niño and La Niña years, respectively, indicating the teleconnection of regional dry/wet variation to ENSO (Fig. 6A). Similar ENSO-related inter-annual precipitation variations have been found in North China (Li et al., 2007; Liu et al., 2009; Chen et al., 2011). In addition, the strong high-frequency biennial cycles (2.0-2.3 years and 2.1 years) fall within the range of tropical biennial oscillation (TBO) variability (its dominant peaks at 2-3 years) (Meehl, 1987).

\section{Acknowledgments}

This work was funded by the National Natural Science Foundation of China Project 41071035, 31100327, 30600093, 31000225 and 31000222 . The work was also supported by the National Science Foundation, USA (NSF), AGS-PRF1137729. We would like to thank the Committee ADA2011 for help on this paper. We also thank Dr. Steven W. Leavitt and the two anonymous reviewers for their constructive comments.

\section{References}

Allan, R., Lindesay, J., Parker, D., 1996. El Niño-Southern Oscillation and Climatic Variability. Commonwealth CSIRO Publishing, Australia.

Briffa, K.R., Jones, P.D., 1990. Basic chronology statistics and assessment. In: Cook, E.R., Kairiukstis, L.A. (Eds.), Methods of Dendrochronology: Applications in the Environmental Sciences. Kluwer Academic Publishers, Dordrecht, pp. 137-152.

Chen, Z.J., Chen, W., He, X.Y., Shao, X.M., Sun, Y., Zhang, C.T., Fu, Y.D., Liu, T.H., 2007. Development of Chinese pine tree-ring width chronology in Fuling Mausoleum, Shenyang of northeast China. Journal of Beijing Forest University 29 (4), $100-109$.

Chen, Z.J., He, X.Y., Cook, E.R., He, H.S., Chen, W., Sun, Y., Cui, M.X., 2011. Detecting dryness and wetness signals from tree-rings in Shenyang, Northeast China. Palaeogeography Palaeoclimatology Palaeoecology 302 (3-4), 301-310.

Cook, E.R., 1985. A Time Series Analysis Approach to Tree-ring Standardization. Ph.D. thesis, The University of Arizona, Tucson, USA.

Cook, E.R., Kairiukstis, L.A., 1990. Methods of Dendrochronology: Applications in the Environmental Sciences. Kluwer Academic Press, Netherlands.

Cook, E.R., Anchukaitis, K.J., Buckley, B.M., D’Arrigo, R.D., Jacoby, G.C., Wright, W.E., 2010. Asian monsoon failure and megadrought during the last millennium. Science 328 (5977), 486-489.

Cai, Q.F., Liu, Y., Bao, G., Lei, Y., Sun, B., 2010. Tree-ring based May-July mean temperature history for Lüliang Mountains, China, since 1836. Chinese Science Bulletin 55 (26), 3008-3014.

Dai, A., Trenberth, K.E., Qian, T., 2004. A global dataset of Palmer Drought Severity Index for 1870-2002: relationship with soil moisture and effects of surface warming. Journal of Hydrometeorology 5, 1117-1130.

Editorial Committee of Academy of Meteorological Science, China Central Meteorological Administration, 1981. Yearly Charts of Dryness/Wetness in China for the Last 500-year Period. Map Publishers, Beijing.

Esper, J., Cook, E.R., Schweingruber, F.H., 2002. Low-frequency signals in long treering chronologies for reconstructing past temperature variability. Science 295 (5563), 2250-2253.

Fang, K.Y., Gou, X.H., Chen, F.H., Yang, M.X., Li, J.B., He, M.S., Zhang, Y., Tian, Q.H., Peng, J.F., 2009. Drought variations in the eastern part of northwest China over the past two centuries: evidence from tree rings. Climate Research 38 (2), 129-135.

Fang, K.Y., Gou, X.H., Chen, F.H., Li, J.B., D’Arrigo, R.D., Cook, E.R., Yang, T., Davi, N. 2010. Reconstructed droughts for the southeastern Tibetan Plateau over the past 568 years and its linkages to the Pacific and Atlantic Ocean climate variability. Climate Dynamics 35 (4), 577-585.

Fritts, H.C., 1976. Tree Rings and Climate. Academic Press, London.

Fu, C.B., Wang, Q., 1991. The abrupt change phenomena of the southern Asian monsoon secular variation and its synchronization with global warming. Science in China (Series B) 6, 666-672.
Gao, S.Y., Lu, R.J., Qiang, M.R., Hasi, E., Zhang, D.S., Chen, Y., Xia, H., 2005. Reconstruction of precipitation in the last 140 years from tree ring at south margin of the Tengger Desert, China. Chinese Science Bulletin 50 (21), 2487-2492.

Gou, X.H., Chen, F.H., Wang, Y.J., Shao, X.M., 2001. Spring precipitation reconstructed in the east of the Qilian Mountain during the last 280 a by tree ring width. Journal of Glaciology and Geocryology 23 (3), 292-296.

Gou, X.H., Deng, Y., Chen, F.H., Yang, M.X., Fang, K.Y., Gao, L.L., Yang, T., Zhang, F. 2010. Tree ring based streamflow reconstruction for the Upper Yellow River over the past 1234 years. Chinese Science Bulletin 55 (36), 4179-4186.

Holmes, R.L., 1983. Computer-assisted quality control in tree-ring dating and measurement. Tree-Ring Bulletin 43, 69-95.

Körner, C., 1998. A re-assessment of high elevation tree line positions and their explanation. Oecologia 115, 445-459.

Li, J.B., Chen, F.H., Cook, E.R., Gou, X.H., Zhang, Y.X., 2007. Drought reconstruction for north central China from tree rings: the value of the Palmer drought severity index. International Journal of Climatology 27 (7), 903-909.

Li, J.P., Zeng, Q.C., 2003. A new monsoon index and the geographical distribution of the global monsoons. Advance in Atmospheric Sciences 20, 299-302.

Liang, E.Y., Shao, X.M., Hu, Y.X., Lin, J.X., 2001. Dendroclimatic evaluation of climategrowth relationships of Meyer spruce (Picea meyeri) on a sandy substrate in semi-arid grassland, north China. Trees-Structure and Function 15 (4) 230-235.

Liang, E.Y., Liu, X.H., Yuan, Y.J., Qin, N.S., Fang, X.Q., Huang, L., Zhu, H.F., Wang, L.L., Shao, X.M., 2006. The 1920s drought recorded by tree rings and historical documents in the semi-arid and arid areas of Northern China. Climatic Change 79 (3-4), 403-432.

Liu, Y., Cai, Q.F., Ma, L.M., An, Z.S., 2001. Tree ring precipitation records from Baotou and East Asia summer monsoon variations for the last 254 years. Earth Science Frontiers 8 (1), 91-97.

Liu, Y., Cai, Q.F., Park, W.K., An, Z.S., Ma, L.M., 2003a. Tree-ring precipitation records from Baiyinaobao, inner Mongolia since AD 1838. Chinese Science Bulletin 48 (11), 1140-1145.

Liu, Y., Park, W.K., Seo, J.W., Jung, H.S., 2003b. Monsoonal precipitation variation in the East Asia since AD 1840-tree-ring evidences from China and Korea. Science in China (Series D: Earth Sciences 46 (10), 1031-1039.

Liu, Y., Shi, J.F., Shishov, V., Vaganov, E., Yang, Y.K., Cai, Q.F., Sun, J.Y., Wang, L., Djanseitov, I., 2004. Reconstruction of May-July precipitation in the north Helan Mountain, Inner Mongolia since AD 1726 from tree-ring late-wood widths. Chinese Science Bulletin 49 (4), 405-409.

Liu, Y., Linderholm, H.W., Song, H.M., Cai, Q.F., Tian, Q.H., Sun, J.Y., Chen, D.L., Simelton, E., Seftigen, K., Tian, H., Wang, R.Y., Bao, G., An, Z.S., 2008. Temperature variations recorded in Pinus tabulaeformis tree rings from the southern and northern slopes of the central Qinling Mountains, central China. Boreas 38, 285-291.

Liu, Y., Bao, G., Song, H.M., Cai, Q.F., Sun, J.Y., 2009. Precipitation reconstruction from Hailar pine (Pinus sylvestris var. mongolica) tree rings in the Hailar region, Inner Mongolia, China back to 1865 AD. Palaeogeography Palaeoclimatology Palaeoecology $282(1-4), 81-87$

Liu, Y., Tian, H., Song, H.M., Liang, J.M., 2010. Tree ring precipitation reconstruction in the Chifeng-Weichang region, China, and East Asian summer monsoon variation since AD 1777. Journal of Geophysical Research-Atmospheres 115 http://dx.doi.org/10.1029/2009jd012330. D06103.

Mann, M.E., Lee, J.M., 1996. Robust estimation of background noise and signal detection in climatic time series. Climatic Change 33, 409-445.

Meehl, G.A., 1987. The annual cycle and interannual variability in the tropical Pacific and Indian Ocean region. Monthly Weather Review 115, 27-50.

Meko, D.M., Graybill, D.A., 1995. Tree-ring reconstruction of Upper Gila River discharge. Water Resources Bulletin 31, 605-616.

Meko, D.M., Stahle, D.W., Griffin, D., Knight, T.A., 2011. Inferring precipitationanomaly gradients from tree rings. Quaternary International 235, 89-100.

Michaelsen, J., 1987. Cross-validation in statistical climate forecast models. Journal of Climate and Applied Meteorology 26, 1589-1600.

Mitchell, T.D., Jones, P.D., 2005. An improved method of constructing a database of monthly climate observations and associated high-resolution grids. International Journal of Climatology 25, 693-712.

Pauling, A., Luterbacher, J., Casty, C., Wanner, H., 2006. Five hundred years of gridded high-resolution precipitation reconstructions over Europe and the connection to large-scale circulation. Climate Dynamics 26 (4), 387-405.

Rolland, C., Michalet, R., Desplanque, C., Petetin, A., Aimé, S., 1999. Ecological requirements of Abies alba in the French Alps derived from dendro-ecological analysis. Journal of Vegetation Science 10, 297-306.

Shao, X., Xu, Y., Yin, Y.Z., Liang, E., Zhu, H., Wang, S., 2010. Climatic implications of a 3585-year tree-ring width chronology from the northeastern Qinghai-Tibetan Plateau. Quaternary Science Reviews 29 (17-18), 2111-2122.

Sun, L., An, G., D, L., S, B.Z., 2000. A climatic analysis of summer precipitation feature and anomaly in northeast China. Acta Meteorologica Sinica 58 (1), 70-82.

Tan, X.M., 2003. Study of major drought catastrophes in China in recent 500 years. Journal of Disaster Prevention and Mitigation Engineering 23 (2), 77-83.

Wang, X.C., Zhang, Q.B., Ma, K.P., Xiao, S.C., 2008. A tree-ring record of 500-year drywet changes in Tibet, China. Holocene 18 (4), 579-588.

Weng, H.Y., Wu, G.X., Liu, Y.M., Behera, S.K., Yamagata, T., 2011. Anomalous summer climate in China influenced by the tropical Indo-Pacific Oceans. Climate Dynamics 36 (3-4), 769-782.

Wigley, T.M.L., Briffa, K.R., Jones, P.D., 1984. On the average value of correlated time series, with applications in dendroclimatology and hydrometeorology. Journal of Applied Meteorology and Climatology 23, 201-213. 
Xiao, Y., 2003. Variation in needle longevity of Pinus tabulaeformis forests at different geographic scales. Tree Physiology 23, 463-471.

Xiong, K.G., Feng, G.L., Huang, J.P., Chou, J.F., 2011. Analogue-dynamical prediction of Monsoon precipitation in Northeast China based on dynamic and optimal configuration of multiple predictors. Acta Meteorologica Sinica 25 (3), 316-326.

Yang, B., Qin, C., Brauning, A., Burchardt, I., Liu, J.J., 2011. Rainfall history for the Hexi Corridor in the arid northwest China during the past 620 years derived from tree rings. International Journal of Climatology 31 (8), 1166-1176.

Yang, Y.K., Liu, Y., Cai, Q.F., Ma, H.Z., Ma, L.M., Guo, J.W., 2005. Precipitation reconstruction from tree ring width over the central Qilian Mountains for the last 248 years. Marine Geology and Quaternary Geology 25 (3), 113-118.

Yi, L., Yu, H.J., Xu, X.Y., Yao, J., Sun, Q., Ge, J.Y., 2010. Exploratory precipitation in north-central China during the past four centuries. Acta Geologica Sinica 84 (1), 223-229.

Yu, D.P., Wang, G.G., Dai, L.M., Wang, Q.L., 2007. Dendroclimatic analysis of Betula ermanii forests at their upper limit of distribution in Changbai Mountain, Northeast China. Forest Ecology and Management 240 (1-3), 105-113.
Yu, D.P., Wang, Q.W., Wang, Y., Zhou, W.M., Ding, H., Fang, X.M., Jiang, S.W., Dai, L.M., 2011. Climatic effects on radial growth of major tree species on Changbai Mountain. Annals of Forest Science 68 (5). http://dx.doi.org/10.1007/s13595011-0098-7.

Zhang, X.L., He, X.Y., Li, J.B., Davi, N., Chen, Z.J., Cui, M.X., Chen, W., Li, N., 2011a. Temperature reconstruction (1750-2008) from Dahurian larch tree-rings in an area subject to permafrost in Inner Mongolia, Northeast China. Climate Research 47 (3), 151-159.

Zhang, Y., Tian, Q.H., Gou, X.H., Chen, F.H., Leavitt, S.W., Wang, Y.S., 2011b. Annua precipitation reconstruction since AD 775 based on tree rings from the Qilian Mountains, northwestern China. International Journal of Climatology 31 (3), $371-381$.

Zou, X.K., Zhai, P.M., Zhang, Q., 2005. Variations in droughts over China: 1951-2003. Geophysical Research Letters 32, L04707.

Zhu, H.F., Fang, X.Q., Shao, X.M., Yin, Z.Y., 2009. Tree ring-based February-April temperature reconstruction for Changbai Mountain in Northeast China and its implication for East Asian winter monsoon. Climate of the Past 5 (4), 661-666. 